\title{
TOWARD MEANINGFUL CIVIC ENGAGEMENT: A CASE STUDY OF CIVIL SOCIETY PARTICIPATION IN LEGISLATIVE REFORM
}

\author{
Karen Allan, Chris Forrester, Leila Patel
}

\section{INTRODUCTION}

Civic engagement, with its focus on involving citizens and civil society organizations in the development of policy and legislation to address matters of public concern, is one vehicle to promote active citizenship and more responsive legislation. In this respect governments consciously seek the views of citizens and social groups and have a genuine interest in achieving outcomes that incorporate their perspectives. Examples of civic engagement are: participation in elections, public policy/legislative processes, public consultations, advocacy, and participation in local community-level decision-making structures.

There is a growing interest in inclusive civic engagement by United Nations agencies, national governments and non-governmental organisations to counteract social exclusion and promote inclusive societies (United Nations Department of Economic and Social Affairs and United Nations Volunteers Programme, 2007). However there are many barriers to effective participation based on social class, age, gender, educational attainment, language, religion, ethnicity, national origin or location. Other reasons why civic engagement is not widely embraced and implemented by governments may be due to: (a) a lack of knowledge, awareness, skills, or the tools to promote engagement; (b) the complexity of managing, resourcing, and implementing engagement processes; (c) obstacles in the operating environment and unfavourable political settings; and (d) the people who lead, control and inhibit participation (United Nations Department of Economic and Social Affairs and United Nations Volunteers Programme, 2007).

Prior to 1994 participation in the formulation of social welfare legislation was limited to selected stakeholders who were favourably disposed to the government. This resulted in policy and legislation that were inappropriate to the local context, as well as being discriminatory and not viable in terms of implementation. In the new democratic context in South Africa there has been a marked shift from exclusive to inclusive policy processes whereby government proactively seeks the views of citizens in its decision-making. Social welfare legislation is currently being developed with the participation of civil society organisations and all parties who have an interest in furthering the needs of specific target groups. The question remains, however, whether the concept of civil society participation in legislative reform is actively embraced by all parties concerned, and whether this approach has indeed proven to be successful in the development of new legislation within the framework of a new democracy.

A case study approach was adopted, firstly, to document and analyse the process of participation of civil society organisations in the development of the Children's Bill, and secondly, to critically appraise the process with a view to developing practice guidelines for all role players in order to enhance effective participation in future legislative reform. The new Children's Bill, of which Section 75 was passed by Parliament in June 2005, was created through a process of public participation. Allan (2006) documented the above process and was a member of the Children's Bill Working Group. The case study provides rich insights into the complexity of government and civil society participation in the process, which was both collaborative and adversarial. 


\section{APPROACHES TO PARTICIPATION IN LEGISLATIVE REFORM}

A social justice and advocacy perspective informed the case study (Jansson, 1999). This perspective is associated with the "transformation of unequal power relations in society", emphasising the "need for social workers to become involved in issues that promote equity and social justice" (Gathiram, 2003:42). The promotion of children's socio-economic rights is advocated in order to significantly improve their wellbeing. The perspective is also aligned with Sections 27 and 28 of the Constitution of the Republic of South Africa (1996) and the United Nations Convention on the Rights of the Child, which was ratified by the South African government in 1994. The Constitution provides for the protection of the legal status and the rights of children, and for the protection of children against neglect and abuse. Poverty is one of the key factors which prevent the realisation of children's socio-economic rights in South Africa today. An estimated 12 million children are living in poverty (Children's Institute, 2006). Approximately 1,2 million children of school-going age are not attending school and many have limited access to nutrition, health care and other basic services (Jacobs, 2005). This situation, coupled with the growing HIV and AIDS epidemic, has had far-reaching consequences for the wellbeing of orphaned and vulnerable children. In recent years there has been an increase in the infant mortality rate from 29 deaths per 1000 live births in 2001 to 43 per 1000 live births in 2005 (Children's Institute, 2008). It is therefore evident that there is a significant gap between the Constitutional provisions for children and the challenges facing society in meeting the needs and promoting the rights of children. A large network of civil society organisations is engaged in delivering services to children and have first-hand knowledge of their needs. Their input into legislative reform from an advocacy and social justice perspective was therefore critical.

The legislative framework developed by Jansson (1999) was used as a guide to study the process of civil society participation. This included an examination of the various phases of the policy/law reform processes, including (a) preparation, which involved the building of agendas, the analysis of problems and the drafting of the legislation; (b) policy advocacy and political processes, referring to strategies to have civil society proposals incorporated into the proposed legislation; (c) the adoption phase, which involves securing the implementation of legislation and in the design of regulations, protocols and guidelines to implement the legislation. The case study focused specifically on the second phase and the roles of the parties in the policy advocacy and political processes.

The concept of participation is a central construct that is firmly situated within the broader theoretical framework of social development which informed the study. The social development perspective provides the foundation for transforming South Africa's welfare system, emphasising human and social rights, which means that it is directed towards "achieving social justice, a minimum standard of living, equitable access and equal opportunities to services and benefits, and a commitment to meeting the needs of all South Africans with a special emphasis on the needs of the most disadvantaged of society" (Patel, 2005:98). Participation remains a key feature of the social development approach. Civil society advocates supported the reform of the Child Care Act of 1983 and participated in the development of the Children's Bill from this rights-based perspective.

Roodt (cited in Gathiram, 2003:42) defines participation as a process whereby "people involve themselves, to a greater or lesser degree, in organisations indirectly or directly concerned with the decision making about, and the implementation of development". Participation is also a process by which government is held accountable for addressing the developmental concerns 
and needs of the most disadvantaged members of a society. Civil society organisations, which included non-state actors concerned with promoting the public good, are key partners with government in a plural arrangement of organisations and institutions. In the case study in question civil society groups working with children represented their interests in the process.

It is important to differentiate between the different sectors, namely government and civil society, as they have different roles and responsibilities in the legislative process. The state, through government departments and Parliament, is responsible for developing laws, while civil society organisations contribute to the content of the legislation being developed. The advocacy role of civil society is of the utmost importance in ensuring that the rights and needs of all citizens are met, especially the most disadvantaged groups (Allan, 2006).

As policies and laws reflect particular political institutions or regimes, it is important to note the history and political context of South Africa which shaped the policy reform process. Prior to 1990 South Africa "followed a largely traditional, Western, industrial world, colonial policy approach" (Cloete, 2000:89). This involved the development of policy by Western political and bureaucratic elites. De Villiers (2001) argues that the transformation process was brought about by the struggle to overcome this state of affairs. After 1990 the policy process was dramatically changed in line with political transformation in South Africa, reflecting a shift in power from minority to majority rule. As stated by Cloete (2000:90): "Government policies were dramatically altered to focus more on the poor, indigenous and underdeveloped communities of the country - the majority - and less on the traditional civilised Western norms and standards of the past".

This shift inevitably impacted on the welfare sector and was translated into the Social Welfare White Paper, 1997. For Patel (2005:113) the idea behind the new legislation "was to amend legislation in the short term to align it with the Constitution and the new policy directions of the democratically elected government after 1994. In the medium to longer term a review of legislation was required to develop comprehensive legislation". The theoretical approach that is most relevant to policy and legislative reform in South Africa after apartheid is referred to as "participatory democracy". Giddens (in Patel, 2005:106) defines this as "a more direct form of decision-making involving those affected by decisions taken". Patel (2005:106) argues that promoters of participatory democracy are "critical of liberal representative democracy", because it is regarded as a "passive form of democracy in which elected representatives take decisions affecting the society". Participatory democracy is closely associated with the concept of civic engagement, which is defined by Cooper (2005:534) as referring to "people participating together for deliberation and collective action within an array of interests, institutions and networks, developing civic identity and involving people in governance processes".

\section{THE CHILDREN'S BILL PROCESS}

The South African Law Commission (SALC) was authorised by the Department of Social Development in 1997 to review the 1983 Child Care Act and draft a new comprehensive Children's Law. The 1983 Child Care Act was seen as inadequate and unconstitutional. The purpose of the review was to bring the legislation in line with section 28 of the Constitution and the United Nations Convention on the Rights of the Child (which was ratified by South Africa in 1994). Sloth-Nielsen (2003) summarised the key issues for consideration as follows: firstly, there was a need to address the link between child protection and children's socio-economic rights; secondly, a comprehensive and coordinated policy was needed involving all parties; and 
finally, other interventions such as early childhood development, prevention and early intervention strategies and the needs of vulnerable children also had to be addressed.

From 1997-2002 the SALC undertook a process involving research, consultation and drafting of the Children's Bill. Civil society organisations were involved in this process. In January 2003 the SALC completed the Draft Bill and submitted it to the Department of Social Development. A process of review of the Draft Bill followed, including consultations with other government departments. This resulted in the first major changes to the Bill which were opposed by civil society organisations. The significantly altered Bill was submitted to Cabinet, which requested further changes. In August 2003 the Cabinet endorsed the altered Bill, which was published for public comment, and the Bill was subsequently certified. However, at the end of 2004 the Bill was declared "a mixed bill" and divided into two bills (s.75 and s.76 Bills).

Early in 2004 the Minister of Social Development called for the Bill to be passed by Parliament before the 2004 elections. Because of time constraints Parliament was unable to study the Draft Bill adequately before the 2004 election campaign. Civil society organisations again opposed rushing the passing of the Bill through Parliament before the April 2004 elections and campaigned for vital sections of the original SALC draft to be re-inserted before the passing of the Bill.

Public hearings on the Section 75 Bill were heard by Parliament in August 2004 in which civil society organisations participated. The Section 75 Bill was passed by the National Assembly on 22 June 2005. As mentioned previously, the focus of the case study involves the process of civil society participation up to the end of 2005. Since then Parliament has passed the Children's Act No. 38 of 2005 and the Children's Amendment Act of 2007. The Regulations are in the process of being finalised and children's organisations are continuing to play a role in this process.

\section{METHODOLOGY}

The main focus of the study involved documenting and developing an understanding of the process of participation from the perspective of civil society advocates. A qualitative design was selected (Fouché \& Delport, 2002). This decision was grounded in interpretivism (Henning, 2004) in that it sought to understand how respondents experienced the process of participation in law reform. It assisted in determining what respondents understood by the concept of participation and in explaining and interpreting the process of participation from the perspective of the civil society organisations that were involved in the formulation of the Children's Bill (Mason, 2002). As the research involved a study of the participation of organisations in a specific legislative process, a case study method was adopted. A case study explores a single entity or phenomenon (the case) bounded by time and activity, and can be "a programme, event, process, institution, or social group" (Creswell in Leedy, 1997:157).

The sample was purposively selected based on the respondents' involvement in the Children's Bill Working Group. A total of 21 organisations were represented in this forum. A sample of 10 civil society organisations was drawn based on predetermined criteria. The respondents had to have prior knowledge of the process; they had to be actively involved and they had to represent a range of sectoral or specialist interests in working with children. The sample was specifically drawn from the working group as it was a population of which the researcher had existing knowledge and participants had proven expertise and experience in the focus of the study. An interview schedule consisting of open-ended questions was used to conduct the interviews. In view of the lack of availability of the participants and the cost factors, six 
interviews were conducted face-to-face and four were conducted telephonically. This was a limitation in that the researcher could not observe the respondents and some important information may have been lost.

The data were analysed manually and by means of a computer software package QSRN6. Tesch's eight steps cited in Cresswell (1994:155) were used as a guide to the data analysis. In order to validate the data externally, a mailed questionnaire was administered to 10 representatives of the Portfolio Committee on Social Development in Parliament who participated in the process. Only two responses were received. The data of the Portfolio Committee members were verified and compared with the responses of the civil society organisations (CSOs) by way of triangulation (Mouton, 1996). The findings are expressed qualitatively but also in percentages merely to indicate the range of views where appropriate.

\section{FINDINGS}

\section{The nature and form of participation}

A total of $80 \%$ of respondents had been involved in other law reform processes since 1994. They brought a high level of skill, expertise and knowledge to the process. A variety of children's rights organisations were represented, which means that they also had specific knowledge of children's issues and their rights. An equal number of participants had both national and provincial organisational experience in working with children. The parliamentarians confirmed this and were of the view that it added value to the process.

The participation of the respondents was assessed in terms of the three phases: preparation, advocacy, and political process and adoption. Only some of the respondents (60\%) participated in the preparation phase and $40 \%$ participated in the adoption phase. Almost all participants (90\%) were involved in the advocacy and political process.

In the preparatory phase respondents contributed to ensuring that children's issues were placed on the policy/law reform agenda. Very few participants were actually involved in drafting the policy/legislation. Two participants sat on the SALC's Committee. The other respondents involved in this phase contributed by providing information, conducting research and contributing to the consultation process. The most important roles which emerged for civil society organisations in the advocacy and law reform process identified by $90 \%$ of respondents were related to advocacy and social mobilisation of their constituencies; raising awareness, writing position papers and discussion of documents; writing formal submissions; making oral submissions and attending public hearings in Parliament, where they also participated in discussions and debates. A large number of participants were involved in lobbying and interacting with parliamentarians (70\%) and attempted to influence their perspectives on children's issues. Other roles included writing media releases, working with the media and cocoordinating the involvement of the constituencies of the civil society organisation networks. In this regard they conducted training of their members and shared information to participate in the debate and prepare their members to make submissions to the Portfolio Committee.

A smaller number of the participants $(40 \%)$ were critical of the role played by government departments and parliamentarians. They were of the opinion that governmental representatives did not know enough about the relevant issues; they did not read the discussion documents and submissions; and they were not sufficiently engaged in the process. As far as the adoption phase is concerned, it needs to be noted that the Bill had not yet been passed and Regulations 
are still being developed. Some participants were only peripherally involved in this phase in terms of having the Bill costed.

\section{The meaning of participation}

Participants had varying notions of the concept of participation. The majority $(70 \%)$ viewed participation as positive. Ten percent of the respondents saw the process of participation as valuable in terms of allowing them to exercise the mandate given to them by their organisations in the sense that they represented particular interest groups and were expected to advocate for those interests. This is line with a fairly widely accepted notion of the value of participation in terms of promoting democratic practices (Cooper, Bryer \& Meek, 2005).

A further $30 \%$ of the participants felt that participation was about drawing on the local experience of those affected by the issue to ensure that policies are effective and responsive to these needs. Various authors underwrite the importance of participation of the public as a means of ensuring appropriate and targeted policies (Lund, 1998; De Villiers, 2001; Murray \& Nijzink, 2002).

Some of the informants of the study (30\%) identified problems with the conceptualisation of participation. One participant indicated that, whilst participation was a constitutional and legal obligation, the actual process of public participation was hindered because not all parliamentarians viewed civil society organisations as a public voice. Another participant agreed with the importance of involving civil society in policy reform, but raised concerns about educating people about the potential and risks of changing policies which may also have major budget implications. This was thought to be particularly relevant in the context of the Growth, Employment and Redistribution (GEAR) policy adopted by the government in 1998, which resulted in constraining government expenditure. Consequently, the recommendations which had financial implications, such as increased social protection for children, were withdrawn from the draft Bill, which was vigorously opposed by CSOs. This indicates that there is no guarantee that the legislation which is finally adopted will reflect the demands of CSOs and that they may have had unrealistic expectations of the likely outcome of their advocacy efforts.

In this respect one participant clearly stated that civil society and government conceptions of what constitutes participation are totally different. The participant was of the opinion that currently the process of participation dictated by government is highly problematic as civil society is only consulted to "rubber stamp" certain changes, whilst the valuable recommendations put forward by civil society are ignored and not integrated into policy and legislation. This led to a feeling of despondency on the part of some respondents, who came to think that the power of civil society to effect real change at a policy or legislative level through their participation is limited. The veto power of government in legislative reform on the grounds of financial affordability can also diminish, or even ignore, the powerful voice of civil society organisations in policy and legislative processes.

\section{Critical appraisal of the process}

The data indicated that all the participants viewed the process as both positive in terms of opportunities for direct participation and negative where there were constraints or obstacles to participation.

Positive aspects associated with the process: 
- The expertise of civil society as a means of improving governments' understanding of children's issues was cited as a positive aspect by half of the respondents. Their involvement in services for children equips them with a relevant voice to bring important grassroots issues to the attention of law makers.

- The importance of the coordination role of the Children's Bill Working Group in advocacy, lobbying and in mobilising their constituencies to participate. Creating awareness, representing the interests of their members and in training and supporting them to make written and oral submissions were vital in giving expression to their opinions.

- The openness of parliamentarians to participation and involvement from civil society organisations creating an enabling environment for participation was noted by close to a third of the respondents.

- A relatively high level of civil society participation was achieved in the Children's Bill process as compared to other policy/law reform processes.

- Exerting significant pressure on government to adopt some CSO recommendations, such as preventing the Bill from being gazetted in a rush prior to national elections.

Some of the negative aspects associated with the process:

- About $60 \%$ of respondents identified the need to strengthen and foster relationships between government and civil society in order to develop meaningful partnerships. The was a lack of transparency and no team approach. Insufficient notice was given to organisations to make submissions and inadequate time was allocated for oral presentations. While the right of CSOs to advocate and lobby needs to be respected, participants were concerned that CSOs had to fight for recognition by public representatives and government officials. The fact that CSOs were organised ensured that their voices were heard. Their role was not automatically acknowledged.

- Civil society organisations lacked knowledge and awareness of the policy/law reform process. Participants also cited the lack of capacity on the part of community and grassroots organisations in drafting and making submissions.

- Participation was found to be an expensive exercise and involved additional costs which had to be borne by CSOs such as travel, printing, production and distribution of information and staff time.

- Insufficient consultation with those affected and direct service providers remains a barrier to participation.

In the section on the meaning of participation above issues were also raised about the limitations of participation and the way in which the government expected CSOs to "rubber stamp" their recommendations.

\section{Recommendations}

Recommendations were made by the participants for improving government's role in the process.

\section{Government}

The majority of participants recommended that government should do more to overcome the barriers to participation such as distance and the costs associated with participation. In order to address this problem, respondents recommended that public hearings should be decentralised; 
that the requirements for submissions be simplified; and that government information needs to be more user friendly and in different languages.

Half of the sample recommended that more should be done to overcome the problem of the lack of awareness about the workings of the law reform process. More effort needs to be made to create public awareness by government and the media, and training of selected groups was needed to equip them to participate more effectively. For example, social workers should have been selected for targeted consultation and awareness-raising, possibly through workshops and dialogue with affected communities and populations at risk. Specific strategies were proposed to improve communication and dialogue between the government and the public to inform them of the opportunities for participation and deadlines. This need for information sharing and training is highlighted by Nakedi (2004:5), who argues that "productive citizen participation can be realised only if information is shared through community education and training". By embracing this notion, active citizenship, as a fundamental tenet of the social development approach, could be enhanced.

A number of informants (40\%) indicated that government should be more open and transparent about the parameters within which government was approaching the process. This may have assisted CSOs in mediating their expectations whilst not giving up their advocacy role. In this regard a respondent indicated that, if a decision was made not to support a programme because of its budget implications, such a decision should be clearly stated upfront to avoid the situation where civil society organisations may be wasting their time working towards something that the government has no intention of implementing.

The need for a clear framework for the participation of CSOs in the development and implementation of law reform processes was also identified. Measures to promote the participation of grassroots organisations and communities need to be specified. In this regard Fakir (2004:6) emphasises the government's constitutional obligation to promote participation and contends that "...in the South African Constitutional sense democracy means active participation or, at least the creation of political space within which participation can occur".

\section{Civil Society}

Lessons learnt from the process for CSOs were also identified. Respondents identified the need for CSOs to be realistic in their submissions, which needed to be solution focused rather than presenting mere descriptions of the problem. Civil society should advocate for issues that can be implemented in practice, that are practical and can be enforced, bearing in mind the available financial and human resources. Camay and Gordon (1998:16) refer to identifying "realistic/winnable issues" and suggest that civil society organisations should evaluate "potential advocacy issues" according to their "capacity to bring about the desired change and to mobilize the support of others to reinforce that capacity".

Several respondents $(40 \%)$ suggested that relationships between civil society and government should be fostered to encourage ongoing dialogue and debate. The same number of participants also recommended that civil society organisations should form alliances with other CSOs when involved in such processes. The identification of a lead organisation/s to coordinate their inputs could strengthen their voice. The value of forming coalitions as an effective advocacy strategy and as a means of engaging with Parliament is highlighted by Watson and Rhoda (2002), who view forming coalitions and partnerships as essential to any strategy or framework for engaging with governments. 
A further $30 \%$ of participants recommended that civil society organisations familiarise themselves with the current and proposed legislation by continually reading and re-reading the Bill in question. They must be clear about their views on the issues and be able to communicate these views to different audiences. These organisations have a responsibility to keep abreast of the issues and the parliamentary debates around them. This process can be enhanced by creating a presence in Parliament and by regularly attending meetings and deliberations.

A strong call was also made to civil society organisations to be prepared and willing to negotiate with government and to learn to compromise on certain issues where necessary.

\section{CONCLUSION}

Civic engagement of the nature described in this case study demonstrates the crucial link between governmental intervention and the practical challenges on grassroots level. It brings the needs of the people to the attention of political decision-makers, who would otherwise not have access to the knowledge of those closely associated with the needs of a particular target population. Participation in such a process crosses the divide between makers of policy/law, the executors and the recipients of these processes. It has the potential to eradicate the distance between macro and micro practice in social work and to impact positively on the lives of the core population for whom it was originally intended.

On-going learning is needed from local experience and to contribute to good practice in order to achieve meaningful civic engagement. A framework to guide participation in policy and legislative processes could go a long way in addressing the barriers to participation and the complexity of the process in which CSOs are both advocates and collaborative partners at the same time. Such a framework should include a set of principles, guidelines and recommendations that could guide the parties in their deliberations. Issues such as negotiations and mediation, the barriers and limits of participation and increasing knowledge, awareness, skills and tools to promote engagement need to be addressed. Further research could also contribute to a good practice model to guide participation in future processes.

South Africa's journey in developing an inclusive society and to strengthen democracy through participatory law-making could inform good practice not only locally but also internationally as governments are being urged to embrace civic engagement more widely. The barriers to effective participation identified in this case study resonate with international experience (United Nations Department of Economic and Social Affairs and United Nations Volunteers Programme, 2007). Civic engagement could go a long way toward deepening democracy through fostering active citizenship as opposed to having passive citizens, who do not exercise their rights to social participation. It is also widely believed that the costs of social exclusion in civic processes are high as it may lead to the adoption of inappropriate policies that may ferment discontent and a loss of public confidence and trust in national governments (Patel, 2008).

\section{REFERENCES}

ALLAN, K. 2006. The participation of civil society organizations in the development of the Children's Bill. Johannesburg: University of Johannesburg. (Unpublished MA Dissertation)

CAMAY, P. \& GORDON, A. (eds) 1998. Advocacy in Southern Africa. Lessons for the future. Johannesburg: Co-operative for Research and Education (CORE). 
412

CHILDREN'S INSTITUTE. 2006. Factors about up-take of the Child Support Grant. Fact Sheet No. 3 of 2006. Cape Town: Children's Institute.

CHILDREN'S INSTITUTE. 2008. South African Child Gauge 2007/2008. Cape Town: University of Cape Town.

CLOETE, F. 2000. Public policy in more and lesser developed states. In: CLOETE, F. \& WISSINK, H. (eds) Improving public policy. Pretoria: Van Schaik Publishers.

COOPER, T.L. 2005. Civic engagement in the twenty-first century: toward a scholarly and practical agenda. Articles from Civic Engagement Initiative Conference. Public Administration Review, 65(5):534-535.

COOPER, T.L., BRYER, T.A. \& MEEK, J.W. 2006. Citizen-centered collaborative public management. Public Administration Review (Special Issue), 66:76-87.

CRESSWELL, J.W. 1994. Research design: qualitative and quantitative approaches. Johannesburg: Sage Publications.

DE VILLIERS, S. 2001. A people's Government. The people's voice. The Parliamentary Support Programme, Cape Town.

DEPARTMENT OF WELFARE. 1997. White Paper for Social Welfare. Government Printer.

FAKIR, E. 2004. Building a strong civil society. Lessons from the field. IDASA Active Citizenship Occasional Paper November 2004. Cape Town: Institute for Democracy in South Africa (IDASA).

FOUCHÉ, C.B. \& DELPORT, C.S.L. 2002. Introduction to the research process. In: DE VOS A.S., STRYDOM, H., FOUCHÉ, C.B. \& DELPORT, C.S.L. (eds). Research at grassroots for the social sciences and human service professions $\left(2^{\text {nd }}\right.$ ed $)$. Pretoria: Van Schaik.

GATHIRAM, N. 2003. Participation, civil society and social work practice. Social Work/Maatskaplike Werk, 39(1):41:47.

GAZETTE NOTICE 1108 OF 1997. Pretoria: Ministry for Welfare and Population Development.

HENNING, E. 2004. Finding your way in qualitative research. Pretoria: Van Schaik.

JACOBS, M. 2005. Children in South Africa. In: JACOBS, M., SHUNG-KING, M. \& SMITH, C. (eds) South African Child Gauge. Cape Town: Children's Institute, University of Cape Town.

JANSSON, B.S. 1999. Becoming an effective policy advocate. Pacific Grove: Brooks/Cole.

LEEDY, P.D. 1997. Practical research planning and design $\left(6^{\text {th }}\right.$ ed $)$. New Jersey: PrenticeHall, Inc.

LUND, F. 1998. Who's in and who's out? The effects of poverty and inequality on participatory institutional development. Olive subscription service: AVOCADO, 2(98).

MASON, J. 2002. Qualitative researching ( $\left.2^{\text {nd }} \mathrm{ed}\right)$. London: Sage Publications.

MOUTON, J. 1996. Understanding social research. Pretoria: Van Schaik. 
MURRAY, A. \& NIJZINK, P. 2002. Building representative democracy. South Africa's Legislators and the Constitution. The European Union Parliamentary Support Programme, Cape Town.

NAKEDI, B. 2004. Moving towards people's power. Lessons from the Field. IDASA Active Citizenship Occasional Paper November 2004. Cape Town: Institute for Democracy in South Africa (IDASA).

PATEL, L. 2005. Social welfare and social development in South Africa. Cape Town: Oxford University Press.

PATEL, L. 2008. Civic engagement, participation, volunteering and social inclusion in national development. Vosesa Focus. Available: http://vosesa.org.za/focus/vol3_no2.

SLOTH-NIELSEN, J. 2003. Promoting children's socio-economic rights through law reform: the proposed Children's Bill. ESR Review: Economic and Social Rights in South Africa, 4(2):2-4.

UNITED NATIONS DEPARTMENT OF ECONOMIC AND SOCIAL AFFAIRS AND THE UNITED NATIONS VOLUNTEERS PROGRAMME. 2007. Expert Group Workshop to examine methods for promoting participation, engagement, including volunteerism, and inclusion in national development initiatives. UN Headquarters, New York, 27-28 November 2007.

WATSON, J. \& RHODA, L. 2002. Women and lawmaking: a study of civil society participation. Public Education Office, Parliament of South Africa, Cape Town.

Ms Karen Allan, Alliance for Children's Entitlement to Social Security; Mr Chris Forrester, Centre for Social Development in Africa, University of Johannesburg; Prof Leila Patel, Centre for Social Development in Africa, University of Johannesburg, Johannesburg, South Africa. 